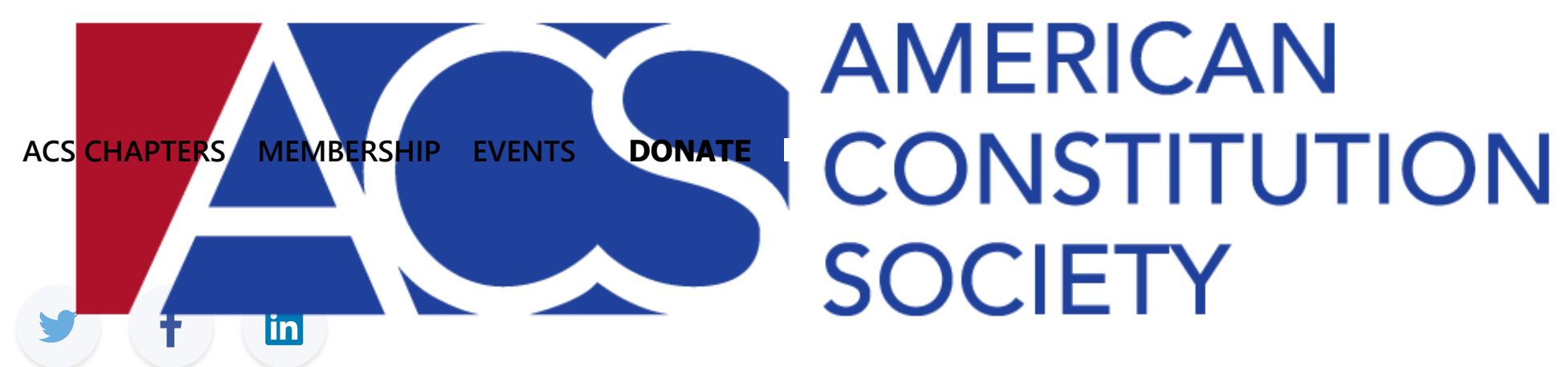

ACS > ACSblog

MARCH 14, 2017

\title{
Private: A Principled Reason to Oppose the Confirmation of Neil Gorsuch
}

\section{Neil gorsuch, Peter M. Shane, Peter shane}

by Peter M. Shane, Professor of Constitutional and Administrative Law at The Ohio State University's Moritz College of Law. The views in this essay are entirely his own.

Contrary to a recently published opinion piece entitled, "There is no principled reason to vote against Gorsuch," many such reasons exist to oppose the nomination of Judge Neil A. Gorsuch to succeed the late Justice Antonin Scalia. This is especially so if you have principled objections to judicial methodologies that purport to constrain judges, but which, in the hands of conservatives, lead quite predictably, even if not quite inevitably to politically conservative outcomes.

But even for Senators who think taking a judge's legal views into account is somehow inappropriate, a perfectly principled reason to oppose the Gorsuch nomination is to avoid rewarding Senate Republicans' 2016 assault on constitutional governance and the Obama presidency. The issue is not just comeuppance for the "mistreatment of Judge Merrick Garland" as a matter of personal unfairness, although I agree "an exceptionally fine jurist was treated shabbily." The issue is whether there remains any institutional penalty for sabotaging constitutional norms. 


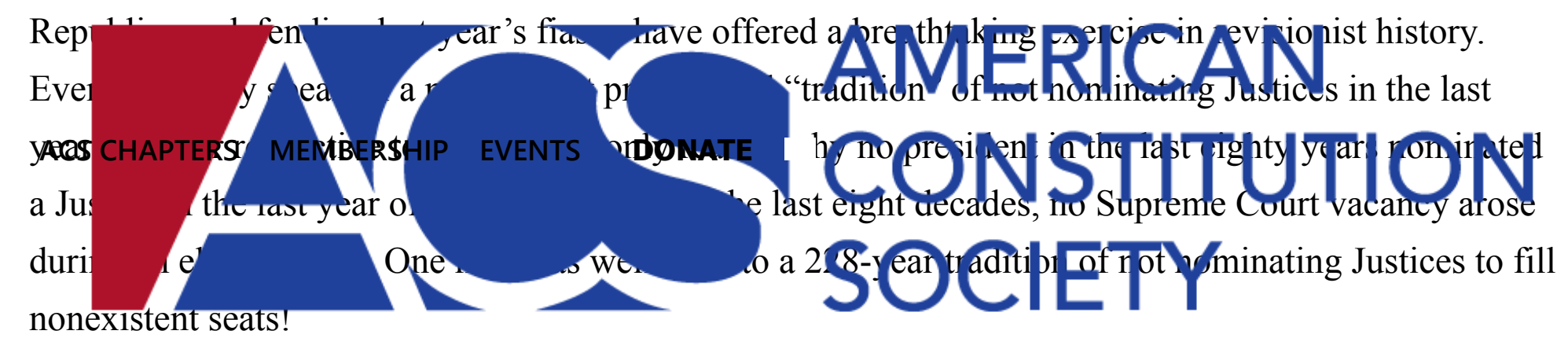

In every relevant sense, the Republicans' obstruction of Judge Garland's nomination was unprecedented. Over the course of two centuries, eight of our 112 Supreme Court Justices were confirmed in the last year of their nominating president's respective terms. Only six times since the country began did the Senate hold a Supreme Court vacancy open for a new president - three times when the nominating president had not been elected (Tyler, Fillmore, and Andrew Johnson) and three times when the nomination was made after a new president had already been elected - most recently in 1881.

Nonetheless, Senate Republicans were not willing to consider Judge Garland at all. They did not merely filibuster the nomination. They denied Judge Garland a hearing. Many Republican Senators refused even to meet with the nominee.

Unlike Senate Republicans who stonewalled the Garland process at every stage, Democrats are not refusing to meet with Judge Gorsuch. They are not declining to read his opinions or assess his record. No one is calling on the Senate Judiciary Committee to deny Judge Gorsuch a hearing or for Democrats to boycott that hearing. Some have even held out the prospect of voting for a Trump nominee if he or she were more in the mold of Judge Garland.

Donald J. Trump has no stronger a mandate to nominate Justice Scalia's successor than did Barack Obama. If anything, it is weaker. Robert A. Paduchik, co-chair of the Republican National Committee, has written that Mr. Trump is fulfilling a promise "to appoint a justice whose views would be consistent with tens of millions of Americans who voted for him." The obvious Democratic response is that they would prefer a justice whose views would be consistent with the millions more Americans who voted for his chief opponent.

In this connection, it is especially worth recalling that both Sens. John McCain (R-AZ) and Ted Cruz (R-TX) indicated there might be no need to fill the Scalia seat if Hillary Clinton were elected 
president — a position Sen. McCain tried to walk back, but which was vigorously applauded before the

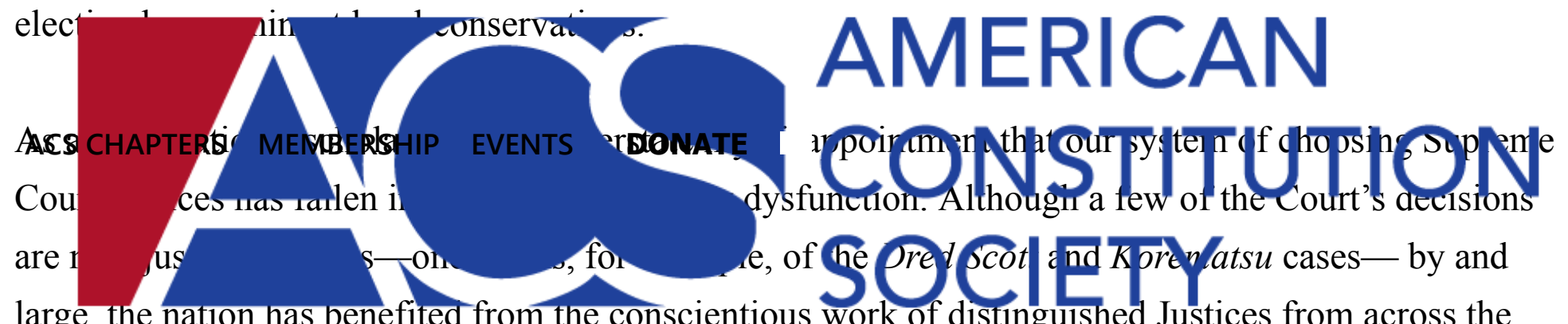
large, the nation has benefited from the conscientious work of distinguished Justices from across the spectrum of jurisprudential thought.

Every senator, Republican and Democrat, owes the country a conscientious assessment of Judge Gorsuch's record. No senator should categorically refuse to consider any nominee on the merits. (And Judge Gorsuch's merits are not beyond debate.)

But a senator may also conscientiously determine that Judge Gorsuch's personal qualifications do not overcome the damage that would come from rewarding unprecedented Republican obstructionism in 2016. That is a principled basis for saying enough is enough.

\section{Related}

\section{ACSBLOG}

\section{Term Limits for Justices are the Best Way to Fix This Supreme Court Mess}

\section{ACSBLOG}

\section{A Sad Week for the Senate, A Devastating Week for the Supreme Court}


ACSBLOG

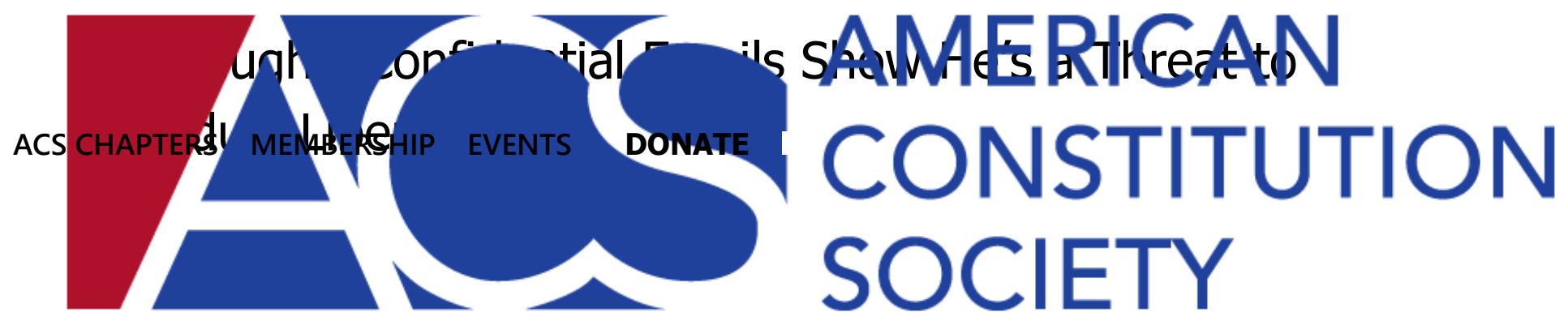

Get Involved

Email

e-Newsletter

SIGN UP

Chapters

Find Your Local Chapter

Join

Become a Part of ACS

DONATE 


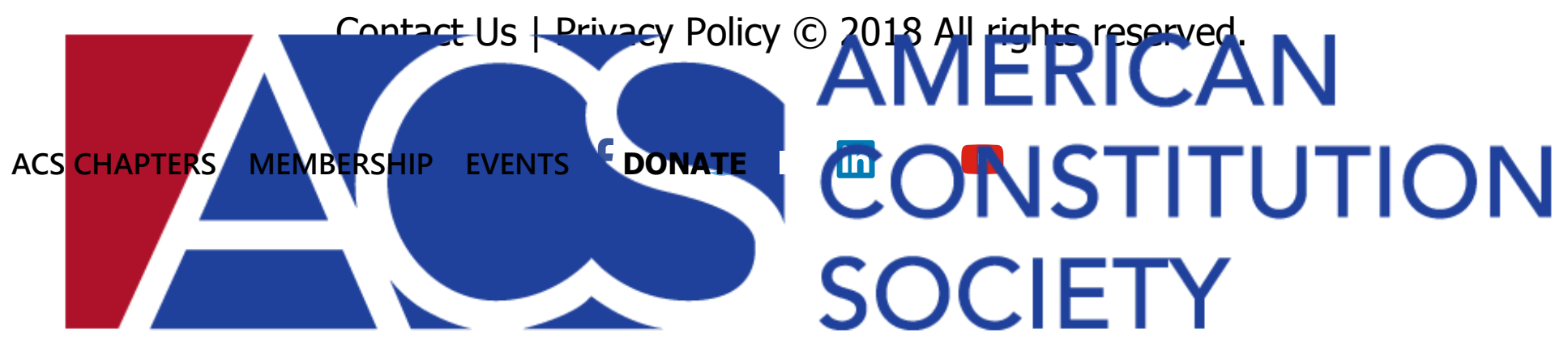

